International Journal of Current Microbiology and Applied Sciences

ISSN: 2319-7706 Volume 10 Number 08 (2021)

Journal homepage: http://www.ijcmas.com

\title{
Effect of Inclusion of Different Locally Available Tree Barks in Total Mixed Ration on Carcass Characteristics and Rumen Fermentation Pattern in Nellore Ram Lambs
}

\author{
Kavya Arekatla $^{1 *}$, B. Devasena ${ }^{1}$, A. Ravi $^{2}$, S. Shakeela $^{3}$ and G. Gangaraju ${ }^{4}$ \\ ${ }^{1}$ Department of Animal Nutrition, College of Veterinary Science, Sri Venkateswara Veterinary \\ University, Tirupati - 517502, India \\ ${ }^{2}$ NTR College of Veterinary Science, Gannavaram, India \\ ${ }^{3}$ Department of Poultry Science, College of Veterinary Science, Sri Venkateswara Veterinary \\ University, Tirupati - 517502, India \\ ${ }^{4}$ Livestock Research Station, Palamaner, India \\ *Corresponding author
}

\section{Keywords}

Tree barks, Nellore ram lambs, Carcass characteristics and Rumen fermentation pattern

Article Info

\section{Accepted:}

15 July 2021

Available Online:

10 August 2021

\section{A B S T R A C T}

An experiment was carried out to study the effect of inclusion of different locally available tree barks in total mixed ration on performance and nutrient digestibility in Nellore ram lambs. A ninety day growth trail was conducted with twenty eight Nellore Jodipi ram lambs $(13.72 \pm 0.05 \mathrm{~kg}$ B.Wt) which were randomly (CRD) allotted to four treatment groups with seven animals per treatment and were fed total mixed ration T1 (control), T2 (10\% Neem bark), T3 (10\% tamarind bark), T4 (10\% Acacia bark). All the four total mixed rations were iso-nitrogenous. Feed intake was recorded daily while, body weights were recorded at weekly intervals. At the end of the trial, four ram lambs per treatment were slaughtered to study effect of total mixed rations containing different tree barks on carcass traits. Rumen liquor was collected from the individual ram lamb and analysed for rumen ammonia $\mathrm{N}$ and TVFA (Total volatile fatty acids) which didn't show any significant difference among different treatment groups. There was no significant $(\mathrm{P}>0.05)$ difference in carcass characteristics like Pre-slaughter weight, dressing percentage, wholesale cuts and weights of organs. The addition of tree barks at $10 \%$ inclusion level in total mixed rations did not show any negative impact on carcass characteristics and rumen fermentation pattern of Nellore Jodipi ram lambs. 


\section{Introduction}

In India, small ruminants are having important economic value to the small and marginal farmers and landless labourers. India has an estimated sheep and goat population of 74.2 million and 144.8 million respectively $\left(20^{\text {th }}\right.$ Livestock census, 2019). Sheep with its multifacet utility for wool, meat, milk, skins and manure, form an important component of rural economy. Despite of fabulous contribution towards economy, its profitability is hampered by poor availability of feed resources and disease management causing high morbidity and mortality and resulting in reduced production. Judicious use of locally available feed resources facilitates economic production. The tree bark is a by-product of paper and timber industry obtained from barkstripping of trunks. Wood pulp and bark residues have been used as energy supplements during periods of critical feed shortage, but have never been generally recognized as alternatives to conventional feed stuffs under normal conditions (Scott et al., 1969). Though wood and bark residues contributes little to the dietary energy needs of ruminants, they can serve as alternatives to conventional roughages. The use of bark in ruminant rations also helps to alleviate the disposal problem of timber industry.

It is likely that many herbivores meet part of their nutrient requirements by consuming unusual plant parts such as bark (Stephens $e t$ al., 2006). Improved animal performance (Min et al., 2012) and a positive impact on Nbalance (Min et al., 2015b) and meeting elevated calcium demands during lactation (Masaki et al., 2004) were observed by using different tree barks. Keeping this in view, the experiment was carried out to study the effect of inclusion of neem, tamarind and acacia tree barks in total mixed ration on carcass characteristics and rumen fermentation pattern in Nellore ram lambs.

\section{Materials and Methods}

Tree barks of neem (Azadirachta indica), tamarind (Tamarindus indica) and acacia (Acacia nilotica) species were collected during the month of January and February from the intact mature trees. An incision was made down the tree trunk vertically with the knife. Bark was scrapped or unwrapped by pushing the knife between outer bark and the cambium. Outer bark was manually separated and naturally flaked dry pieces of bark were also collected, dried, ground and stored. Dried samples of tree bark, were analysed for proximate principles (AOAC, 2005). The total phenolic compounds and non-tannin phenolic compounds present in the tree bark samples were estimated according to the procedure given by Makkar et al., (1993). The amount of condensed tannins present in the sample was estimated according to the procedure described by Porter et al., (1985).

Four iso-nitrogenous complete rations were formulated (CP 16.25\% Average) and were designated as $\mathrm{T} 1, \mathrm{~T} 2, \mathrm{~T} 3$ and $\mathrm{T} 4$. In $\mathrm{T} 1$ (control), Super Napier grass (Pennisetum purpureum) and groundnut straw (Arachis hypogaea) were incorporated at $30 \%$ level each, along with concentrate ingredients at $40 \%$ level. Whereas, T2, T3 and T4 comprised Super Napier grass and groundnut haulms at $25 \%$ level each, along with concentrate ingredients added at $40 \%$ level. Different tree barks viz., Neem, Tamarind and Acacia were added at $10 \%$ level in total mixed rations $\mathrm{T} 2$, $\mathrm{T} 3$ and $\mathrm{T} 4$, respectively.

Twenty eight Nellore ram lambs (at Sheep Project Unit, Livestock Research Station, Palamaner) of 3-4 months age and of uniform conformation were selected and divided by completely randomized block design (CRD) into four groups of seven animals in each and were subjected to feeding trial of 90 days. Throughout the experimental period, the 
measured quantity of TMR was offered daily in the morning and evening to individual animals and leftover was collected the next morning to determine daily feed intake. Fresh drinking water was made available throughout the day. The body weight of the individual animal was recorded at fortnightly intervals in the morning before feeding and watering. At the end of 90 day growth trail, four ram lambs per each treatment were slaughtered to study effect of total mixed rations containing different tree barks on carcass traits. Rumen contents were collected at time of slaughter and filtered through four layers of muslin cloth and approximately $100 \mathrm{ml}$ of filtrate was collected and few drops of concentrated sulfuric acid was added and stored at $-20^{\circ} \mathrm{C}$ for further analysis. Rumen liquor was analysed for $\mathrm{NH} 3 \mathrm{~N}$ and TVFA as per the procedure given by AOAC (2005).

Immediately after slaughter, meat sample (Longissimus dorsi) was collected and stored at $-20^{\circ} \mathrm{C}$ for further analysis (proximate analysis as per AOAC, 2005). The data obtained were subjected to analysis through software (version 23.0; SPSS, 2015) by applying one-way analysis of variance through generalized linear model and the treatment means were ranked using Duncan's multiple range test with a significance at $\mathrm{P}<0.05$ (Duncan,1955).

The experimental protocols that were developed in this study were fully complied with the ethical principles of animal experimentation prepared by Institutional animal ethic committee (IAEC) with reference number 281/ go/ S/ 2000/ CPCSEA/ CVSc/ TPTY/ 012/ ANN/ 2020.

\section{Results and Discussion}

The chemical composition of total mixed ration indicated that $\mathrm{DM}, \mathrm{CP}$ and $\mathrm{EE}(\%)$ contents were similar (Table 1) among the different rations and were iso-nitrogenous with CP content of $16.25 \%$ (Average). The amount (\%) of total phenolic compounds, condensed tannins and hydrolysable tannins found to be more in Acacia bark, followed by Neem, and Tamarind (Table 2).

The data obtained from the experiment on the slaughter parameters of ram lambs were presented in Table 3 indicated non-significant $(P>0.05)$ effect on ram lambs fed four dietary treatments.

There is no significant difference in final body weight among different groups with the values $22.45,21.65,22.26$ and 22.02 in T1, T2, T3 and T4, respectively. Dressing percentage and organs weights (Kidney, Liver, Heart, Testes and Spleen) did not show significant difference among the treatment groups.

Similar to the present research results, Min et al., (2015b) and Reynolds et al., (2019) also reported non-significant difference in carcass characteristics between treatment groups supplemented with pine bark.

The carcass characteristics of meat animals is majorly influenced by plane of nutrition and carcass characteristics are well known to respond gradually to changes in nutrition and longer periods of feeding may be needed to exhibit any effects (Min et al., 2012). Present trial was relatively short, lasting for 90 days, thereby expecting no difference in carcass characteristics.

The data on whole sales cuts of ram lambs fed different tree barks at $10 \%$ level were presented in the Table 4. There was no significant $(\mathrm{P}>0.05)$ difference in whole sale cuts of ram lambs among the treatments. Similar to the present study, Chaves et al., (2011) reported that supplementation with cinnamon bark powder did not alter the weights of any primal cuts of meat. 
Table.1 Chemical composition (\%) of total mixed rations containing different tree barks*

\begin{tabular}{|c|c|c|c|c|}
\hline Parameter & T1 & T2 & T3 & T4 \\
\hline DM & 94.68 & 94.67 & 94.64 & 94.64 \\
\hline OM & 84.89 & 82.53 & 83.84 & 86.57 \\
\hline CP & 16.30 & 16.27 & 16.21 & 16.23 \\
\hline CF & 20.64 & 20.24 & 21.78 & 22.25 \\
\hline EE & 1.23 & 1.16 & 1.12 & 1.15 \\
\hline TA & 15.11 & 17.47 & 16.16 & 13.43 \\
\hline NFE & 46.72 & 44.86 & 44.73 & 46.94 \\
\hline
\end{tabular}

Table.2 Phenolic constituents present in different tree barks

\begin{tabular}{|c|c|c|c|}
\hline Compound & Neem bark & Tamarind bark & Acacia bark \\
\hline Total phenolic compounds (\%) & 0.322 & 0.267 & 0.841 \\
\hline $\begin{array}{c}\text { Non-tannin phenolic compounds } \\
(\%)\end{array}$ & 0.119 & 0.117 & 0.124 \\
\hline Pure tannins (\%) & 0.266 & 0.165 & 0.776 \\
\hline Condensed tannins (\%) & 0.09 & 0.02 & 0.20 \\
\hline Hydrolysable tannins (\%) & 0.176 & 0.145 & 0.576 \\
\hline
\end{tabular}

Table.3 Carcass characteristics of ram lambs fed total mixed rations containing different tree barks

\begin{tabular}{|c|c|c|c|c|}
\hline Charecteristics & T1 & T2 & T3 & T4 \\
\hline Live weight at slaughter $(\mathrm{kg})$ & $22.45 \pm 0.62$ & $21.61 \pm 0.71$ & $22.26 \pm 0.87$ & $22.02 \pm 0.54$ \\
\hline Dressing percentage $(\%)$ & $48.13 \pm 0.59$ & $47.49 \pm 3.03$ & $46.71 \pm 1.57$ & $46.52 \pm 1.99$ \\
\hline Weight of skin $(\mathrm{kg})$ & $2.37 \pm 0.16$ & $2.28 \pm 0.16$ & $2.28 \pm 0.30$ & $2.44 \pm 0.20$ \\
\hline Weight of head $(\mathrm{kg})$ & $1.50 \pm 0.86$ & $1.38 \pm 0.10$ & $1.27 \pm 0.11$ & $1.51 \pm 0.05$ \\
\hline Weight of feet $(\mathrm{kg})$ & $0.72 \pm 0.07$ & $0.69 \pm 0.02$ & $0.72 \pm 0.04$ & $0.71 \pm 0.01$ \\
\hline Weight of blood $(\mathrm{kg})$ & $0.87 \pm 0.06$ & $0.76 \pm 0.08$ & $0.86 \pm 0.05$ & $0.87 \pm 0.03$ \\
\hline \multicolumn{4}{|c|}{ Organ weight } \\
\hline Kidneys $(\mathrm{kg})$ & $0.106 \pm 0.01$ & $0.103 \pm 0.006$ & $0.106 \pm 0.01$ & $0.103 \pm 0.005$ \\
\hline Liver $(\mathrm{kg})$ & $0.41 \pm 0.03$ & $0.40 \pm 0.04$ & $0.40 \pm 0.04$ & $0.39 \pm 0.01$ \\
\hline Spleen $(\mathrm{kg})$ & $0.108 \pm 0.01$ & $0.102 \pm 0.007$ & $0.105 \pm 0.01$ & $0.108 \pm 0.006$ \\
\hline Heart $(\mathrm{kg})$ & $0.09 \pm 0.008$ & $0.09 \pm 0.01$ & $0.09 \pm 0.01$ & $0.10 \pm 0.007$ \\
\hline Testes $(\mathrm{kg})$ & $0.09 \pm 0.004$ & $0.09 \pm 0.01$ & $0.09 \pm 0.008$ & $0.09 \pm 0.004$ \\
\hline
\end{tabular}

Table.4 Wholesale cuts of ram lambs fed total mixed rations containing different tree barks

\begin{tabular}{|c|c|c|c|c|}
\hline Wholesale cuts & T1 & T2 & T3 & T4 \\
\hline Neck \& shoulder $(\mathrm{kg})$ & $1.16 \pm 0.08$ & $1.21 \pm 0.05$ & $1.26 \pm 0.17$ & $1.15 \pm 0.07$ \\
\hline Brisket \& fore shank $(\mathrm{kg})$ & $3.58 \pm 0.27$ & $2.98 \pm 0.22$ & $3.54 \pm 0.36$ & $3.08 \pm 0.15$ \\
\hline Loin $(\mathrm{kg})$ & $1.17 \pm 0.06$ & $1.22 \pm 0.09$ & $1.27 \pm 0.04$ & $1.35 \pm 0.10$ \\
\hline Rack $(\mathrm{kg})$ & $1.33 \pm 0.27$ & $1.57 \pm 0.13$ & $1.32 \pm 0.05$ & $1.31 \pm 0.11$ \\
\hline Leg $(\mathrm{kg})$ & $3.54 \pm 0.34$ & $3.29 \pm 0.38$ & $3.00 \pm 0.14$ & $3.36 \pm 0.12$ \\
\hline
\end{tabular}


Table.5 Chemical composition of the longissimus dorsi of ram lambs fed total mixed rations containing different tree barks (On fresh basis)

\begin{tabular}{|c|c|c|c|c|}
\hline Parameter & T1 & T2 & T3 & T4 \\
\hline Dry matter (\%) & $28.35 \pm 0.54$ & $27.81 \pm 1.03$ & $26.67 \pm 1.10$ & $28.50 \pm 3.31$ \\
\hline $\begin{array}{c}\text { Crude protein } \\
(\%)\end{array}$ & $22.72 \pm 0.45$ & $22.96 \pm 0.37$ & $20.69 \pm 2.16$ & $23.19 \pm 0.62$ \\
\hline Ether extract (\%) & $2.01 \pm 0.13$ & $2.13 \pm 0.10$ & $1.96 \pm 0.42$ & $2.07 \pm 0.57$ \\
\hline
\end{tabular}

Table.6 Rumen fermentation pattern of ram lambs fed total mixed rations containing different tree barks

\begin{tabular}{|c|c|c|c|c|}
\hline Parameter & T1 & T2 & T3 & T4 \\
\hline Ammonia N (mg/100ml) & $8.2 \pm 0.35$ & $7.8 \pm 1.1$ & $8.3 \pm 0.62$ & $7.9 \pm 0.93$ \\
\hline TVFA (mMol/L) & $104.7 \pm 2.9$ & $98.6 \pm 1.9$ & $101.5 \pm 1.5$ & $96.6 \pm 2.5$ \\
\hline
\end{tabular}

The chemical composition of longissimus dorsi muscle of ram lambs fed total mixed rations containing different tree barks at $10 \%$ level was shown in Table 5. The crude protein content of the muscle was 22.72, 22.96, 20.69 and 23.19 in $\mathrm{T} 1$ to $\mathrm{T} 4$, respectively. The dietary treatments did not significantly $(\mathrm{P}>$ 0.05) influence the chemical composition of Longissimus dorsi muscle of ram lambs.

Development of muscle depends on nutrient composition and utilization, therefore the energy and protein contents of the diet might partly explain the difference in chemical composition of muscle (Wood et al., 2003). In the present study, ram lambs offered isonitrogenous supplementations, thereby expecting no difference in the proximate composition of Longissimus dorsi muscle of ram lambs.

Rumen fermentation pattern of ram lambs fed total mixed rations containing different tree barks at $10 \%$ level was presented in Table 6. There was no significant $(\mathrm{P}>0.05)$ difference in ammonia $\mathrm{N}$ concentration among the different treatment groups and the values were $8.2,7.8,8.3$ and 7.9 in $\mathrm{T} 1$ to $\mathrm{T} 4$, respectively. There was no significant $(\mathrm{P}>0.05)$ difference in TVFA concentration among the different treatment groups with the values 104.7, 98.6, 101.5 and 96.6 in $\mathrm{T} 1, \mathrm{~T} 2, \mathrm{~T} 3$ and $\mathrm{T} 4$, respectively. In contrast to present study, decreased ammonia $\mathrm{N}$ concentration was reported by Carulla et al., (2005); Min et al., (2012); Yang et al., (2016); Soltan et al., (2018) and Vera et al., (2018). This reduction in ammonia $\mathrm{N}$ concentration as reported by the various authors suggesting that condensed tannins present in the bark, which forms the complexes with the proteins causing reduced protein degradation in the rumen that might have resulted in reduced ammonia $\mathrm{N}$ concentration.

In the present study, due to the minimal concentrations of condensed tannins (0.02 to $0.2 \%$ ) present in the tree barks which resulted in non-significant difference in ammonia $\mathrm{N}$ concentration and as a result no change in TVFA concentration was observed. This is in agreement with Min et al., (1999) who also opinioned that the presence of trace amount of condensed tannins $(1-2 \mathrm{~g} / \mathrm{Kg} \quad \mathrm{DM})$ is considered too low to affect rumen fermentation.

The current study indicated that the addition of tree barks at $10 \%$ inclusion level in total mixed rations did not show any negative 
impact on carcass characteristics, muscle composition and rumen fermentation pattern of Nellore Jodipi ram lambs.

\section{References}

AOAC, 2005. Official methods of Analysis (18th Ed) Association of Official Analytical chemists Washington DC.

Carulla, J. E., Kreuzer, M, Machmuller, A.and Hess, H. D. 2005. Supplementation of Acacia mearnsii tannins decreases methanogenesis and urinary nitrogen in forage-fed sheep. Australian Journal of Agricultural Research, 56(9): 961-970.

Chaves, A. V., Dugan, M. E. R., Stanford, K., Gibson, L. L., Bystrom, J. M., McAllister, T. A. and Benchaar, C. 2011. A dose-response of cinnamaldehyde supplementation on intake, ruminal fermentation, blood metabolites, growth performance, and carcass characteristics of growing lambs. Livestock Science, 141(2-3): 213-220.

Duncan, D. B. 1955. Multiple range and multiple F tests. Biometrics 11(1): 142

Livestock Census All India Report DAHD and F, 2019. Ministry of Animal Husbandry, Dairying and Fisheries, Ministry of Agriculture, Government of India. (www.dahd.nic.in).

Makkar, H. P., Blummel, M., Borowy, N. K.and Becker, K. 1993. Gravimetric determination of tannins and their correlations with chemical and protein precipitation methods. Journal of the Science of Food and Agriculture, 61(2): 161-165.

Masaki, A., Yokota, H. O.and Shibata, E. I. 2004. Why do sika deer, Cervus Nippon, debark trees in summer on Mt. Ohdaigahara, central Japan? Mammal Study, 29(1): 73-83.
Min, B. R., McNabb, W. C., Barry, T. N., Kemp, P. D., Waghorn, G. C.andgg, M. F. 1999. The effect of condensed tannins in Lotus corniculatus upon reproductive efficiency and wool production in sheep during late summer and autumn. The Journal of Agricultural Science, 132(3): 323-334.

Min, B. R., Solaiman, S., Gurung., Behrends., J. Eun, J. S. Taha. and Rose, J. 2012. Effects of pine bark supplementation on performance, rumen fermentation, and carcass characteristics of Kiko crossbred male goats. Journal of Animal Science, 90(10): 3556-3567.

Min, B. R., Solaiman, S., Terrill, T., Ramsay, A.and Mueller-Harvey, I. 2015b. The effects of tannins-containing ground pine bark diet upon nutrient digestion, nitrogen balance, and mineral retention in meat goats. Journal of Animal Science and Biotechnology, 6(1): 25.

Porter L J, Hrstich L N and Chan B G 1985. The conversion of procyanidins and prodelphinidins to cyanidin and delphinidin. Phytochemistry, 25(1): 223-230.

Reynolds, D., Min, B. R., Gurung, N., McElhenney, W., Lee, J. H., Solaiman, S.and Bolden-Tiller, O. 2019. Influence of tannin-rich pine bark supplementation in the grain mixes for meat goats: Growth performance, blood metabolites, and carcass characteristics. Journal of Animal Nutrition, 6(1): 85-91.

Scott R, W., Millett, M. A.and Hajny, G. J. 1969. Wood wastes for animal feeding. Forest Products Journal, 19(4): 14-18.

Soltan, Y. A., Hashem, N. M., Morsy, A. S., El-Azrak, K. M., El-Din, A. N.and Sallam, S. M. 2018. Comparative effects of Moringa oleifera root bark and monensin supplementations on ruminal fermentation, nutrient digestibility and growth performance 
of growing lambs. Animal Feed Science and Technology, 235: 189201.

Stephens, S. A., Salas, L. A. and Dierenfeld, E. S. 2006. Bark Consumption by the Painted Ringtail (Pseudochirulus forbesi larvatus) in Papua New Guinea. Biotropica, 38(5): 617-624.

Vera, N., Gutiérrez, C., Allende, R., Williams, P., Fuentealba, C.and Ávila-Stagno, J. 2018. Dose-response effect of a pine bark extract on in vitro ruminal ammonia and methane formation kinetics. Acta Agriculturae Scandinavica, Section A-Animal
Science, 68(4): 181-189.

Wood, J. D., Richardson, R. I., Nute, G. R., Fisher, A. V., Campo, M. M., Kasapidou, E., Sheard, P. R. and Enser, M. 2003. Effect of fatty acids on meat quality: a review. Meat Science 66: 21-32.

Yang, S. Y., Ningrat, R. W. S., Eun, J. S.and Min, B. R. 2016. Effects of supplemental virgin coconut oil and condensed tannin extract from pine bark in lactation dairy diets on ruminal fermentation in a dual-flow continuous culture system. Advances in Dairy Research, 1-6.

\section{How to cite this article:}

Kavya Arekatla, B. Devasena, A. Ravi, S. Shakeela and Gangaraju, G. 2021. Effect of Inclusion of Different Locally Available Tree Barks in Total Mixed Ration on Carcass Characteristics and Rumen Fermentation Pattern in Nellore Ram Lambs. Int.J.Curr.Microbiol.App.Sci. 10(08): 334-340. doi: https://doi.org/10.20546/ijcmas.2021.1008.040 